\title{
Skeletal metastases from renal cell carcinoma: diagnostic uncertainty with molecular imaging
}

\author{
Swaroop Revannasiddaiah, ${ }^{1}$ Ashwani Sood, ${ }^{2}$ Priyanka Thakur, ${ }^{1}$ Mukesh Sharma ${ }^{1}$ \\ 1Department of Radiation Therapy and Oncology, Regional Cancer Center, Indira Gandhi Medical College, Shimla, Himachal Pradesh, India \\ ${ }^{2}$ Department of Nuclear Medicine, Postgraduate Institute of Medical Education and Research, Chandigarh, India
}

Correspondence to Dr Swaroop Revannasiddaiah, swarooptheone@gmail.com

\section{DESCRIPTION}

A 54-year-old patient underwent right radical nephrectomy for what was then diagnosed as a Stage-II (T2bN0M0) renal cell carcinoma (RCC). Four months after surgery, the patient reported of pelvic pain and had a rising serum alkaline-phosphatase level. The tecnetium- 99 mmethylene-diphosphate (Tc99m-MDP) bone scan then demonstrated a focus of uptake in the right ischium, corresponding to the locus of pain (figure 1). As part of further metastatic work-up, a whole body ${ }^{18} \mathrm{~F}$-fluorodeoxyglucose positron-emission tomography (FDG-PET) scan was performed; this however could not demonstrate any anomalies (figure 2). Six months after surgery (2 months after the first scan) the patient complained of generalised bony pains. Then, metastatic disease was confirmed when reimaging (with chest radiograph and a repeat bone scan) showed pulmonary and vertebral metastases (figure 3).

Two commonly used molecular-imaging techniques in the general evaluation of skeletal metastases are the bone scan and the FDG-PET scan. Whereas the bone scan is dependent on bone turnover, the FDG-PET scan depends on increased glucose uptake by cancerous cells, often accompanied by upregulated glucose transporter 1 (GLUT-1) expression. With RCC, however, FDG-PET uptake is less likely to have a correlation with GLUT-1 expression, hence limiting the role of FDG-PET in RCC. ${ }^{1} 2$

In conclusion, an investigation of possible bone metastasis from RCC warranted in the presence of bone pains and/or elevated alkaline-phosphatase levels. Bone scan is a common first-line investigation, although FDG-PET is another option. However, one should appreciate that there is a $30 \%$ false-negative rate associated with both. Further, since both the tests rely on different molecularuptake mechanisms, the results of either test may or may not concur with the other.

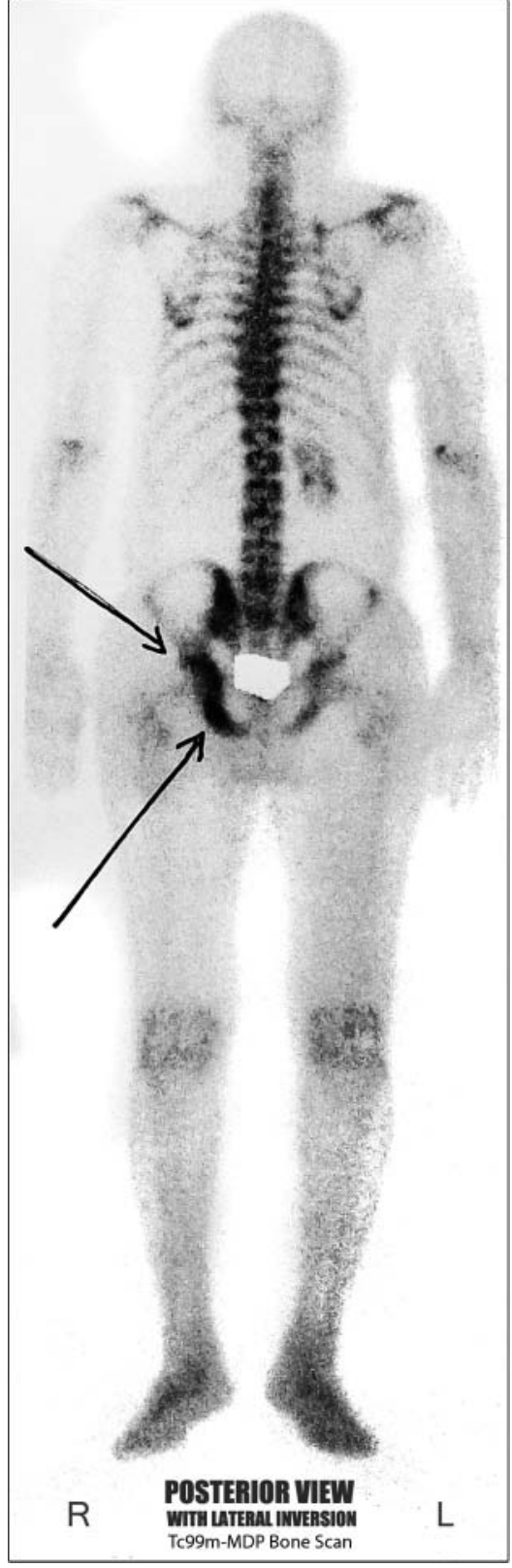

Figure 1 Tecnetium-99m-methylene-diphosphate bone scan image showing an area of increased tracer uptake in the right hemi-pelvis, corresponding to the clinical locus of pain (4 months after surgery). 


\section{BMJ Case Reports}

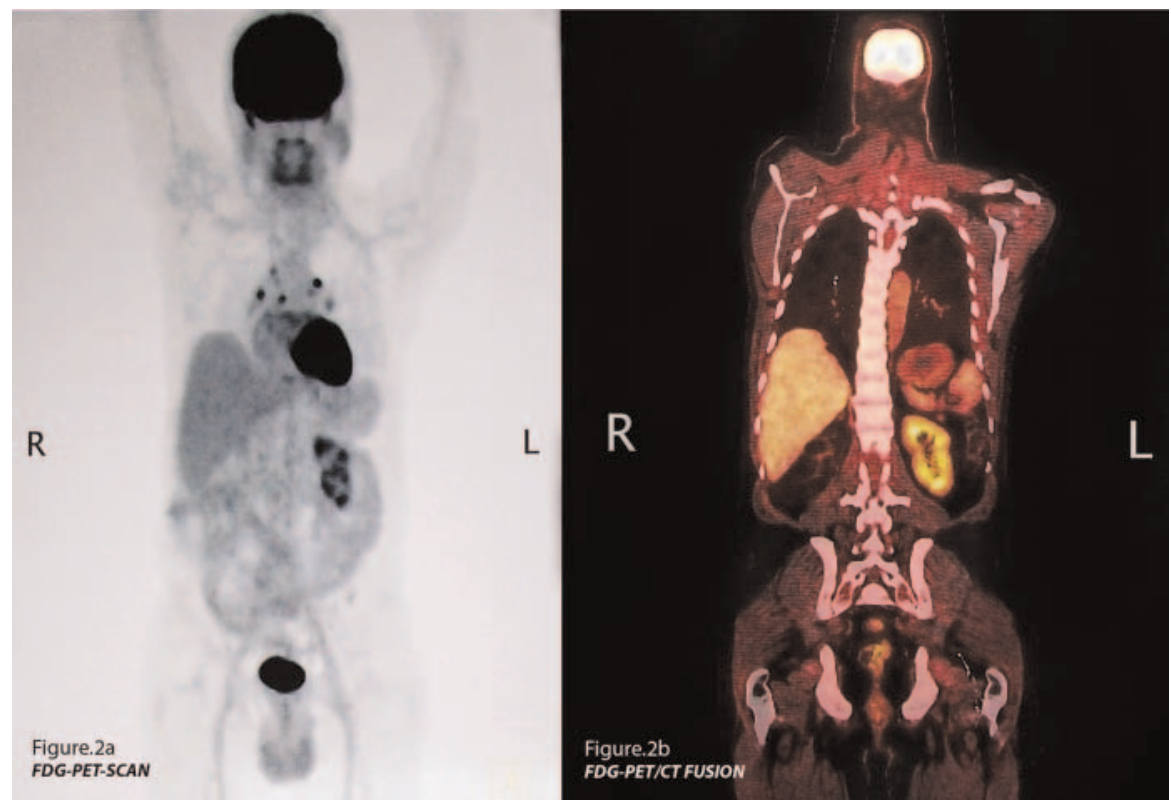

Figure $2{ }^{18} \mathrm{~F}$-fluorodeoxyglucose positron-emission-tomography (FDG-PET) maximum-intensity projection view (A) and FDG-PET/CT fusion (B) images visualising no anomalous uptake in the pelvis (4 months after surgery).
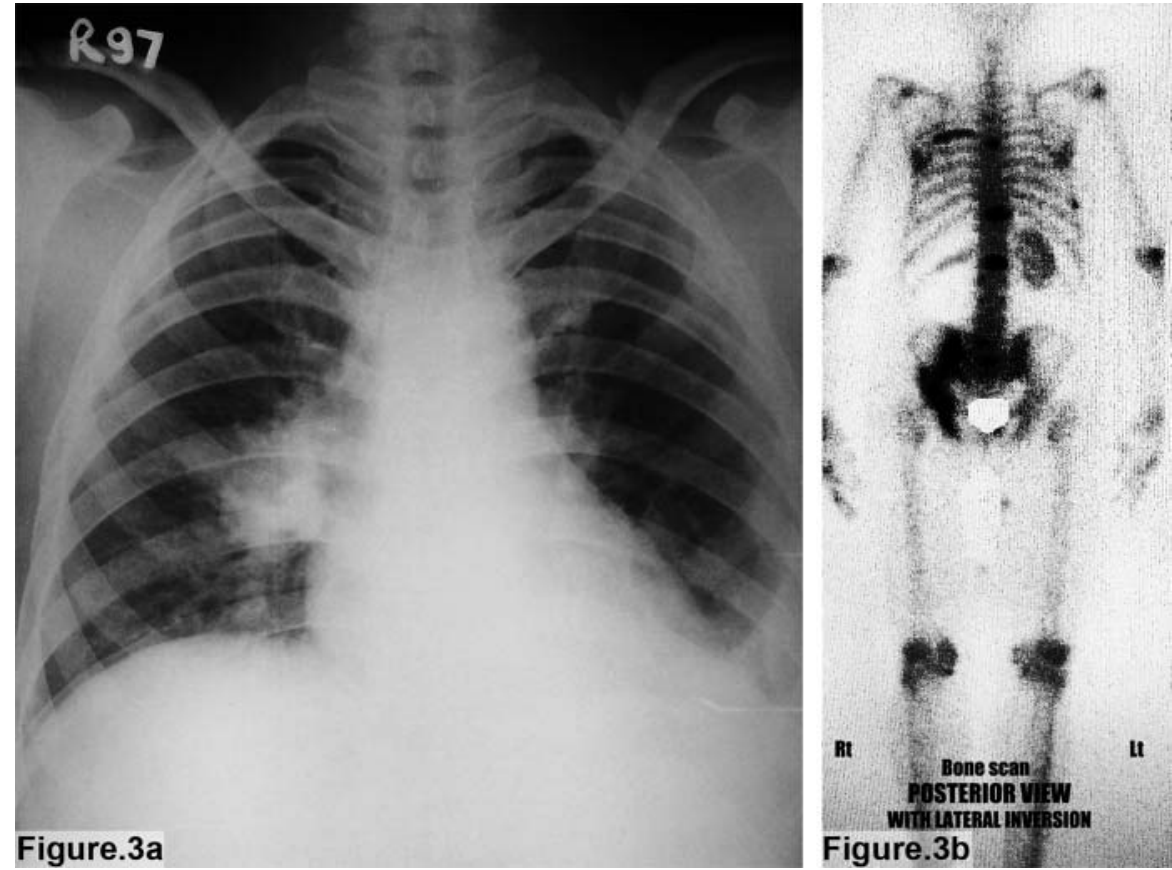

Figure 3 Right-sided lung metastasis $(A)$ and a repeat bone scan image $(B)$ revealing progressive metastatic disease (6 months after surgery). 


\section{Learning points}

- X-ray radiography and a serum alkaline phosphatase level measurement should be the first investigations in patients with suspected skeletal metastases from renal cell carcinoma.

- Skeletal metastases from renal cell carcnioma may not be readily demonstrable with the use of FDG-PET scans.

- The bone scan and the FDG-PET scan are both associated with a $30 \%$ false-negative rate in the detection of skeletal metastatic disease from renal cell carcinoma.
Competing interests None

Patient consent Obtained.

\section{REFERENCES}

1. Majhail NS, Urbain JL, Albani JM, et al. F-18 fluorodeoxyglucose positron emission tomography in the evaluation of distant metastases from renal cell carcinoma. J Clin Oncol 2003;21:3995-4000.

2. Miyakita H, Tokunaga M, Onda $\mathrm{H}$, et al. Significance of ${ }^{18} \mathrm{~F}$-fluorodeoxyglucose positron emission tomography (FDG-PET) for detection of renal cell carcinoma and immunohistochemical glucose transporter 1 (GLUT-1) expression in the cancer. Int J Urol 2002;9:15-18.

3. Griffin N, Gore ME, Sohaib SA. Imaging in metastatic renal cell carcinoma. Am J Roentgenol 2007;189:360-70.

This pdf has been created automatically from the final edited text and images.

Copyright 2012 BMJ Publishing Group. All rights reserved. For permission to reuse any of this content visit http://group.bmj.com/group/rights-licensing/permissions.

BMJ Case Report Fellows may re-use this article for personal use and teaching without any further permission.

Please cite this article as follows (you will need to access the article online to obtain the date of publication).

Revannasiddaiah S, Sood A, Thakur P, Sharma M. Skeletal metastases from renal cell carcinoma: diagnostic uncertainty with molecular imaging. BMJ Case Reports 2012;10.1136/bcr.02.2012.5910, Published XXX

Become a Fellow of BMJ Case Reports today and you can:

- Submit as many cases as you like

- Enjoy fast sympathetic peer review and rapid publication of accepted articles

- Access all the published articles

- Re-use any of the published material for personal use and teaching without further permission

For information on Institutional Fellowships contact consortiasales@bmjgroup.com

Visit casereports.bmj.com for more articles like this and to become a Fellow 